\title{
サーマルマネキンの潜熱抵抗測定精度向上及び 防護服の顕熱抵抗測定に関する研究紹介
}

\section{上野哲*1}

衣服を構成する生地の物理的性質だけでは, 着衣の温熱特性を予測することは不可能であるため, 温熱特性 の計測には人と同じ形状をしたサーマルマネキンが使われる．現在，環境評価やモデル計算との関連等の広い 分野でサーマルマネキンは応用されている，本研究紹介では，労㗢安全衛生総合研究所の清瀬地区にあるサー マルマネキンを使った $2 つ の$ 研究成果を紹介する。一つは，防火服の暑熱ストレス評価のためにサーマルマネキ ンを使って行った顕熱抵抗測定した研究である．歩行により顕熱抵抗は減少し，サイズ・材質によって減少の 割合は異なった。次は, 同サーマルマネキンを使って, スウェットスーツ上の水分蒸発部分における表面温度を 正確に測定することで潜熱抵抗測定の高精度化を行い，測定技術を向上させた研究である．マネキンの埋め込 み温度センサーで測定した表面温度を使用すると潜熱抵抗が過大評価されることがわかった。

キーワード：サーマルマネキン，衣服，顕熱抵抗，潜熱抵抗

\section{1 サーマルマネキンとは}

人は環境に応じた衣服をまとうことで，衣服と皮膚 の間に微気候（衣服気候）を形成し環境制御を行ってい る ${ }^{1)}$. 各衣服の持つ保温性 (顕熱抵抗) 及び透湿性（潜熱 抵抗）はサーマルマネキンを用いて計測することが可能 である。サーマルマネキンとは, 人と同じ形状のマネキ ンに発熱ヒーターと温度センサーを埋め込多制御ソフト ウェアーで表面温度を制御できるように作られた装置で ある. マネキンはいくつかのゾーンに分割されており, ゾーンごとに発熱量や表面温度が独立して制御できるよ うになっている. 衣服を構成する生地の保温性, 透湿性 を測定しただけでは，着衣の保温性，透湿性を予測する ことができない. そのため, 人と同形のサーマルマネキ ンに測定対象の衣服を着せて, 人が衣服を着用したのと 同じ状況を作って衣服の温熱特性を測定する，衣服の温 熱特性の計測を被験者実験ではなくてサーマルマネキン で行う利点は, サーマルマネキンを構成するシェルの厚 さが薄いため, 定常状態に達するまでの時間が短く, 計 測が正確で, 再現性がよいことである. 被験者実験でも 計測可能であるが，個人差が大きいこと，同じ個人でも 日によって状態が異なること，人だと動くことが避けら れないことなど䛊差となる要因が多数存在する. 被験者 実験ではできない環境条件でもサーマルマネキンでは測 定できる等利点は大きい，現在では，サーマルマネキン は熱収支の理論計算と組み合わせで用いたり ${ }^{2)}$, 温熱環 境の評価のために用いたり ${ }^{3,4)}$, 衣服の温熱特性計測以 外にも多方面で利用されている。

原稿受付 2014年2月14日（Received date: February 14, 2014） 原稿受理 2015年9月18日 (Accepted date: September 18, 2015) J-STAGE Advance published date: January 14, 2016

*1 (独) 労働安全衛生総合研究所 有害性評価研究グループ 連絡先：干224-8585 神奈川県川崎市多摩区長尾 6-21-1 （独）労働安全衛生総合研究所 有害性評価研究グループ 上野 哲

E-mail: uenos@h.jniosh.go.jp doi: 10.2486/josh.JOSH-2015-0008-KE

\section{2 サーマルマネキンの特徵と性能}

実験で用いたサーマルマネキン（NEWTON, Measurement Technology Northwest社, シアトル) の特徴及び 性能を以下に述べる。マネキンの大きさはアジア人男性

\begin{tabular}{cc} 
表1 & マネキンのサイズ \\
\hline & $\begin{array}{c}\text { 長さ } \\
(\mathrm{cm})\end{array}$ \\
\hline 全高 & 169 \\
胸囲 & 91 \\
肩幅 & 40 \\
ウェスト & 75 \\
股下 & 72 \\
ヒップ & 91 \\
\hline
\end{tabular}

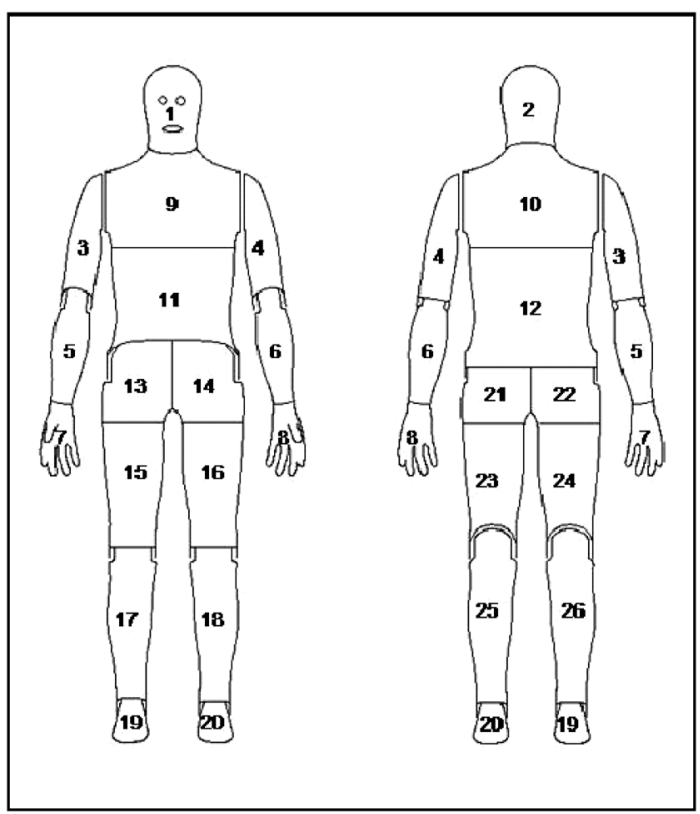

図 1 マネキンの26ゾーン (参考文献 ${ }^{5)}$, 表 1 , 図 1より) 
の平均の体格である (表1). サーマルマネキンの総体表 面積は $1.8 \mathrm{~m}^{2}$ で, 26のゾーンから成り立ち (図 1), それ ぞれ温度センサーと発熱抵抗線が埋め込まれている.

温度センサーは表面下 $0.5 \mathrm{~mm}$ の所に埋め込まれてお り，アルミニウムにエポキシを混ぜた薄い層でコーティ ングされている. 発熱線は, 温度センサーとは断熱材の 膜を隔てた深いところに等しい間隔で埋め込まれてゾー ン内の表面温度が均一になるように工夫されている. 温 度上昇中のサーマルマネキンをサーモグラフで撮影する と, 発熱線が埋め込まれた部分の温度が高く, 発熱線の 間の領域は温度が低いため埋め込まれた発熱線の部分を 見分けることができる. 時間がたって表面温度が均一に なると, 発熱線をサーモグラフィーで見分けることはで きなくなる. 発熱線の材質は, 線膨張率の低いワイヤー $\left(0.0015 \% /{ }^{\circ} \mathrm{C}\right)$ であるため, 温度による変形が少ない. 各ゾーンには, 温度や発熱量を制御するためのコント ローラがあり, パソコン上の制御ソフトからの情報に基 づいて表面温度, 発熱量を制御する. 表面温度は $\pm 0.1^{\circ} \mathrm{C}$ の範囲で制御が可能であり, 単位面積あたりの発熱量は $800 \mathrm{~W} / \mathrm{m}^{2}$ まで増やすことができる. マネキンには両手 と両足に棒をつけ, その棒がモーターにつながり歩行を 模擬した動きが可能である. 最大 60 歩/分の歩行が可 能であるため, ヨーロッパのサーマルマネキンの規格で あるENV3426) を満たしている。このサーマルマネキン は, 顕熱抵抗の測定基準の ASTM F12917) 及び潜熱抵抗 の測定基準であるASTM F $2370^{8)}$ に沿った測定が可能で ある。

\section{3 サーマルマネキンを使つた顕熱抵抗研究紹介}

労㗢作業において断熱性が高い防護服を着用するだけ で暑熱ストレスが高まることがよく知られている9 。そ の中で，防火服は最も暑熱ストレスが大きいものの一つ であり, 訓練時に熱中症になる消防士が多い. 消防士が 着用する防火服の暑熱ストレスを軽減するためにサイ ズ, 材質が異なる防火服が次世代防火服研究会で作成さ れ，作成された防火服の顕熱抵抗の評価を行った ${ }^{5}$.

サイズが異なる 3 種類（M, L, LL）の基本防火服と $\mathrm{M}$ サイズの 2 種類（ $\mathrm{Ye}$ : パラアラミド, $\mathrm{Br}$ : ザイロン）の 材質の異なる防火服の顕熱抵抗を測定した。 そのほか, 消防士が消防活動以外の通常の事務作業時に着用する 2 種類の活動服（AB：基本, AS：ストレッチ型）を測定し た (表2).

立位静止状態と歩行状態（45歩/分）の着衣の顕熱抵 抗を示す (図2). 着衣顕熱抵抗の測定は, 全ゾーン表面 温度 $34^{\circ} \mathrm{C}$ の条件で計測しパラレル法を使って計算した。 パラレル法は, 表面温度が全ゾーンで同じであるときに 有効な計算方法で，以下の式で表される.

$$
I_{T}=\frac{\sum_{i} \alpha_{i} \cdot\left(T_{\mathrm{sk}_{i}}-T_{o}\right)}{\sum_{i}\left(\alpha_{i} \cdot H_{i}\right)}=\frac{T_{\mathrm{sk}}-T_{o}}{\sum_{i}\left(\alpha_{i} \cdot H_{i}\right)}
$$

ここで, $T_{\mathrm{sk}_{i}}: i$ ゾーンの平均表面温度 $\left[{ }^{\circ} \mathrm{C}\right], T_{o}$ : 環境の

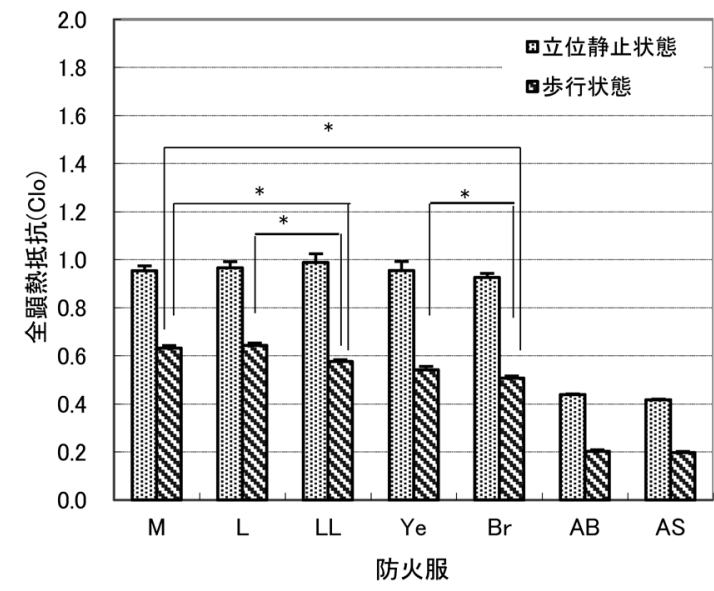

図2 防火服と活動服のみの全顕熱抵抗（参考文献 ${ }^{5}$, 図2より)

表2 各防火服のサイズと材質

\begin{tabular}{|c|c|c|c|}
\hline \multirow[t]{4}{*}{ 防火服 } & \multicolumn{2}{|c|}{ サイズ } & \multirow[t]{4}{*}{ 材質 } \\
\hline & 上着 & ズボン & \\
\hline & & （ウェスト- & \\
\hline & & 股下)(cm) & \\
\hline M & M サイズ & $83-70$ & メタアラミド 90 \\
\hline $\mathrm{L}$ & Lサイズ & $90-70$ & メタアラミド 90 \\
\hline LL & LL サイズ & $98-70$ & メタアラミド 90 \\
\hline Ye & M サイズ & $83-70$ & パラアラミド \\
\hline $\mathrm{Br}$ & M サイズ & $83-70$ & PBO(ザイロン) \\
\hline $\mathrm{AB}$ & Lサイズ & $83-70$ & 上着（綿 $50 \%+$ \\
\hline \multirow[t]{4}{*}{ （活動服） } & & & ポリエステル \\
\hline & & & $50 \%)$ \\
\hline & & & ズボン（メタア \\
\hline & & & ラミド 75\%他） \\
\hline AS & 同上 & $83-70$ & ズボンのみスト \\
\hline （活動服） & & & レッチ型 \\
\hline
\end{tabular}

作用温度 $\left[{ }^{\circ} \mathrm{C}\right], \alpha_{i}$ : マネキン全表面積に対するiゾーン

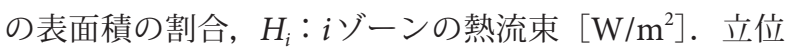
静止状態は歩行状態よりいずれのタイプの防火服におい ても着衣顕熱抵抗は大きかった，立位静止状態では，サ イズや材質の違いによる着衣顕熱抵抗の相違はなかっ た．歩行状態では，LLがLや M と比較して有意に着衣 顕熱抵抗が小さかった.

材質では, BrがYeやMより有意に低い顕熱抵抗值と なった。活動服の $\mathrm{AB}, \mathrm{AS}$ は防火服の半分以下の顕熱抵 抗值であった (図2).

部位ごとでは, 立位静止状態で慰部, 腹部, 背部等の衣 服内空気層が厚い部分の顕熱抵抗が大きかった（図3）. 顔や頭，手や足はマネキンがむき出しになっているため, 着衣顕熱抵抗值がゼロになった。歩行状態では, 全部位 において着衣顕熱抵抗の低下が見られ, 体幹部で最も減 少した. 上着の裙が動くことで防火服の外から空気が流 れ込んだと考えられる. 雉部でLLサイズが最も歩行時 の減少率が大きかったのは, 上着の裾とズボンの長い重 なりが歩行によってなくなり, 上着の裾の部分が榍部の 


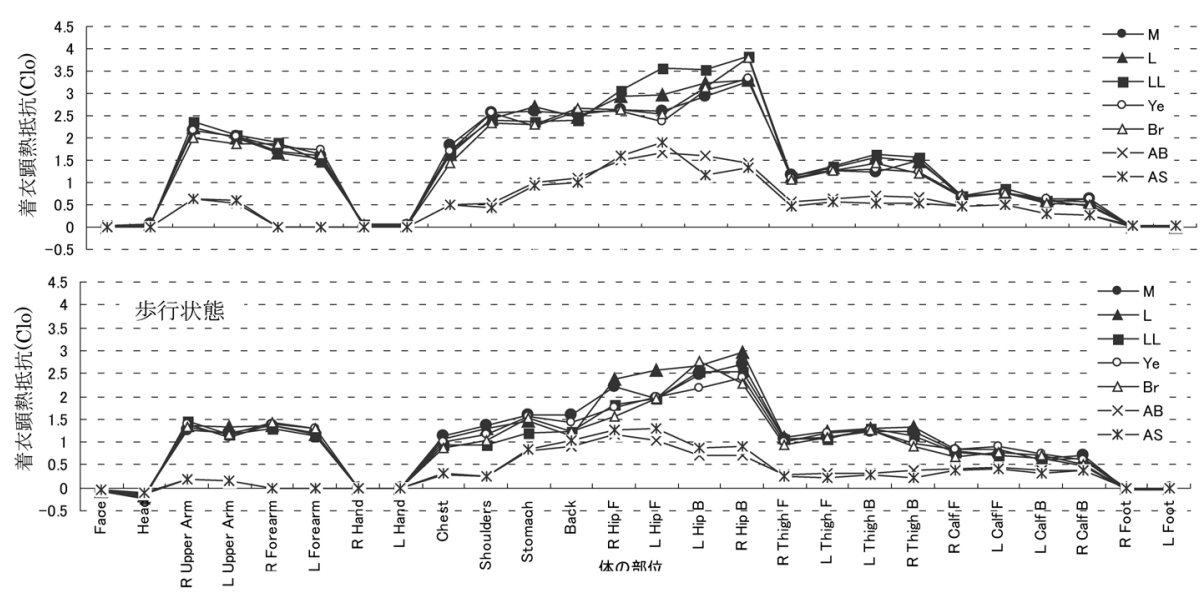

図3 ゾーンごとの防火服と活動服のみの顕熱抵抗（参考文献 ${ }^{5)}$, 図3より）

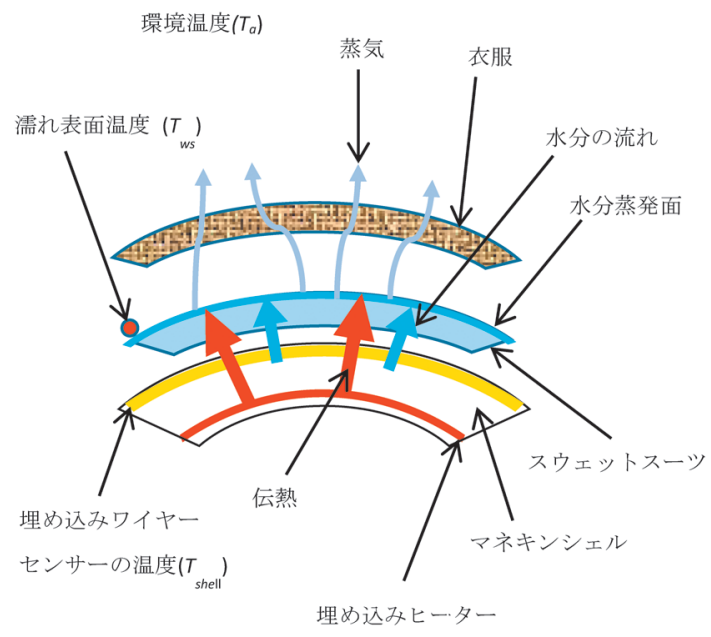

図4 潜熱抵抗測定時のサーマルマネキン，スウェットスーツ及び 衣服の断面図

顕熱抵抗に寄与しなくなったからだと考えられる。

\section{4 サーマルマネキンによる潜熱抵抗測定の 精度向上の研究紹介}

サーマルマネキンを使って潜熱抵抗測定をするとき は, マネキン全表面から水が蒸発するように濡れたス ウェットスーツで全表面を覆う。通常, 表面温度は計測 の利便性から通常マネキンの表面近くに埋め込まれたワ イヤーセンサーで計測された温度 $\left(T_{\text {shell }}\right)$ を使うが, 表 面が需れた状態では水分が蒸発するスウェットスーツ 上の温度 $\left(T_{\mathrm{ws}}\right)$ が表面温度となる. 我々 ${ }^{10)}$ は $T_{\mathrm{ws}}$ を表 面温度として正確に測定し, 潜熱抵抗を正確に求めた。 図 4 に測定時のサーマルマネキンの断面図を模式的に示 す。マネキン表面の埋め込み温度センサーからスウェッ トスーツの上面との間に温度抵抗と熱流移動があれば, 次の式により $T_{\text {shell }}$ と $T_{\mathrm{ws}}$ の間に温度差が生じることにな る.

$$
T_{\text {shell }}-T_{\text {ws }}=Q * I_{\text {shell-ws }} / A_{\text {Du }}>0
$$

ここで, $Q$ ：全発熱量 $[\mathrm{W}], A_{\mathrm{Du}}$ : マネキンの全表面 積 $\left[\mathrm{m}^{2}\right], I_{\text {shell-ws }}$ : マネキン埋め込みの表面温度センサー

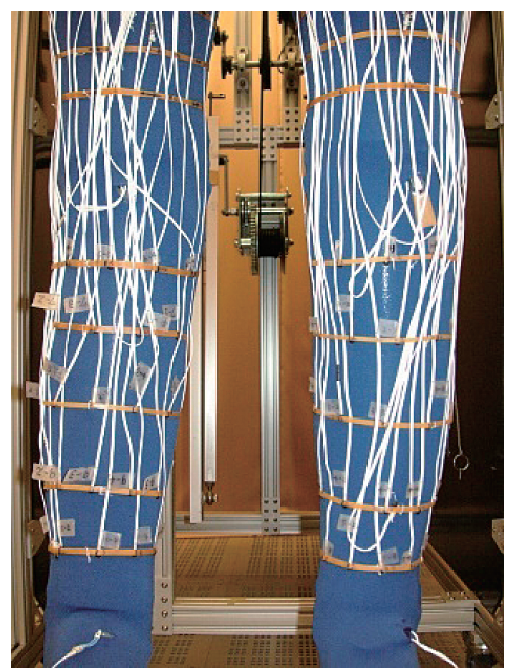

図 5 各ゾーンの平均表面温度を計測するための温度センサーの 位置決め用の測定

の位置からスウェットスーツ上面の間の熱抵抗 $\left[{ }^{\circ} \mathrm{C} \cdot \mathrm{m}^{2} /\right.$ W] である. $I_{\text {shell-ws }}$ は予測できないため, 直接 $T_{\mathrm{ws}}$ の温度 を表面温度センサーで測定した．20個のマネキンの各 ゾーンに15-24個のサーミスターを配置し, ゾーンの平 均表面温度にできるだけ近い温度になるように各ゾーン から 4 所サーミスターの位置を選び出した（図 5)。実 際の測定では, 各ゾーン内の選んだ 4 か所に表面温度セ ンサーを縫いつけ, 測定した4つの温度の平均值をゾー ンの平均表面温度とした。最初に，裸のマネキンの表面 温度を 3 種類の方法で測定し比較した（図6）。3つの方 法は以下の通りである. (方法 1): 従来の埋め込み温度セ ンサーでの測定，（方法2）：スウェットスーツ上をサー ミスターでの測定, (方法3）: サーモグラフィー（TVS700, NEC AVIO, Japan）での測定．方法3では，サーモ グラフィーで濡れたスウェットスーツの写真を撮り，そ の写真から専用解析ソフト (PE professional, NEC Avio, Japan）を使いゾーンごとの二次元面の平均表面温度を 求めた。 サーミスターの平均表面温度が埋め込みセン サーの温度よりも低いこと, 及びサーミスターとサーモ グラフィーの温度がほとんど等しいことがわかり，サー

Vol. 9, No. 1, pp. 43-48, (2016) 
ミスターによる表面温度の計測が正確であることを示し た（図6）。次に，表3に示す 4 種類の衣服の組み合わせ で全潜熱抵抗及び表面温度を測定した。実験条件はマネ キンの埋め込み温度センサーの温度が $34.0^{\circ} \mathrm{C}$ 一定, 人工 気象室の環境温度は $34.0^{\circ} \mathrm{C}$, 相対湿度は $50 \%$ とした。 そ の結果, $T_{\text {shell }}=T_{\mathrm{a}}=34.0^{\circ} \mathrm{C}>T_{\mathrm{ws}}$ となったため, マネキン 内部のヒーターと環境の両側から水分の蒸発面に向かっ て熱が伝えられることとなる. そのため, 蒸発の潜熱に 使われる熱量は，（3）式で表される.

$$
Q=\sum_{i=1}^{20}\left[Q_{i}+\left(T_{o}-T_{\mathrm{ws}_{i}}\right) A_{i} / I_{t_{i}}\right]
$$

ここで, $Q_{i}: i$ ゾーンの発熱量 $[\mathrm{W}], T_{\mathrm{ws}}: i$ ゾーンの ウェットスーツ上の表面温度 $\left[{ }^{\circ} \mathrm{C}\right], T_{0}$ : 環境の作用温度 $\left[{ }^{\circ} \mathrm{C}\right], A_{i}:$ iゾーンの表面積 $\left[\mathrm{m}^{2}\right], I_{t_{i}}: i$ ゾーンにおける 衣服の顕熱抵抗 $\left[{ }^{\circ} \mathrm{C} \cdot \mathrm{m}^{2} / \mathrm{W}\right]$ である. 人工気象室は長時 間 $34^{\circ} \mathrm{C}$ に保っていたため, 放射温度と環境温度は等し

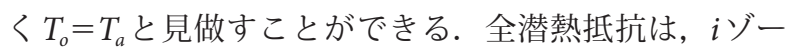
ンのウェットスーツ上の表面温度 $T_{\mathrm{ws}_{\mathrm{i}}}$ をマネキンのゾー ンの面積で加重平均した全ウェットスーツ上の平均表面 温度 $T_{\mathrm{ws}}$ を使い（5）式で表される.

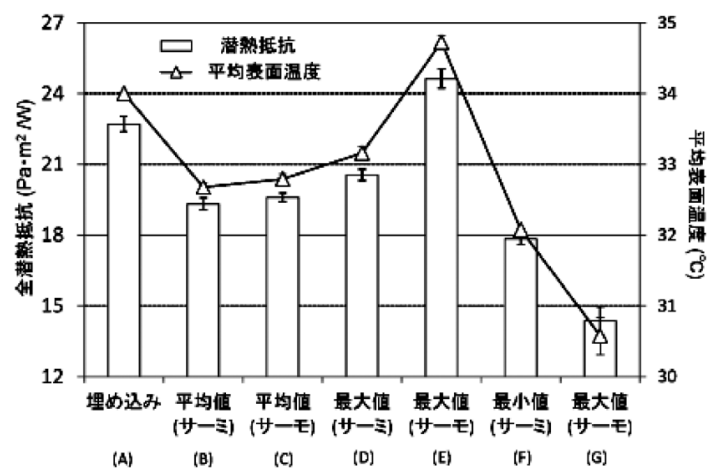

図6 裸のサーマルマネキンの全潜熱抵抗と表面温度 （A）マネキン埋め込みセンサーを使って計測した場合.（B）各 ゾーン4個の表面温度センサーを平均して計算した場合. (C) 各 ゾーン 4 個の表面温度センサーの最大值で計算した場合. (D) 各 ゾーン 4 個の表面温度センサーの最小值で計算した場合. (E) 各 ゾーンの表面温度をサーモグラフィーで測定した平均温度とした 場合.（F）各ゾーンの表面温度をサーモグラフィーの最大温度と した場合. (G) 各ゾーンの表面温度をサーモグラフィーの最低温 度とした場合.

$$
\begin{aligned}
& T_{\mathrm{ws}}=\sum_{i=1}^{20} \frac{A_{i}}{A_{\mathrm{Du}}} \times T_{\mathrm{ws}_{i}} \\
& R_{\mathrm{et}}=\frac{P\left(T_{\mathrm{ws}}\right)-P\left(T_{a}\right) \times R H}{Q} \times A_{\mathrm{Du}}
\end{aligned}
$$

ここで, $R_{\mathrm{et}}$ : 全潜熱抵抗 $\left[\mathrm{kPa} \cdot \mathrm{m}^{2} / \mathrm{W}\right], P\left(T_{\mathrm{ws}}\right): T_{\mathrm{ws}}$ における飽和蒸気圧 $[\mathrm{kPa}], P\left(T_{a}\right): T_{a}$ における飽和蒸 気圧 $[\mathrm{kPa}], R H$ : 相対湿度, $A_{\mathrm{Du}}$ : マネキンの全表面 積 $\left[\mathrm{m}^{2}\right], A_{i}: i$ ゾーンの表面積 $\left[\mathrm{m}^{2}\right]$ である. 各部位の ウェットスーツ上の平均表面温度 $T_{\mathrm{ws}}$ の温度は, (2) 式 から熱流束と $I_{\text {shell-ws }}$ が求まれば計算できる. そのため, 図7に示すように各ブロックで4種類の衣服（表3）を4 種類の状態（静止状態，歩行速度 $0.96 \mathrm{~km} / \mathrm{h}, 1.92 \mathrm{~km} / \mathrm{h}$, $2.88 \mathrm{~km} / \mathrm{h}$ ）で測定した平均熱流束と平均表面温度をプ ロットすることで理論式（6１1）を導いた。

$$
\begin{aligned}
& T_{\text {shell }}-T_{\text {ws }}=H_{\text {Arm }}\left(\mathrm{W} / \mathrm{m}^{2}\right) \times 0.0130 \text { (Arm) } \\
& T_{\text {shell }}-T_{\mathrm{ws}}=H_{\text {Trunk }}\left(\mathrm{W} / \mathrm{m}^{2}\right) \times 0.0089 \text { (Trunk) } \\
& T_{\text {shell }}-T_{\mathrm{ws}}=H_{\text {Hip }}\left(\mathrm{W} / \mathrm{m}^{2}\right) \times 0.0115 \text { (Hip) } \\
& T_{\text {shell }}-T_{\text {ws }}=H_{\text {Thigh }}\left(\mathrm{W} / \mathrm{m}^{2}\right) \times 0.0063 \text { (Thigh) } \\
& T_{\text {shell }}-T_{\mathrm{ws}}=H_{\text {Calf }}\left(\mathrm{W} / \mathrm{m}^{2}\right) \times 0.0071 \text { (Calf) } \\
& T_{\text {shell }}-T_{\text {ws }}=H_{\text {All }}\left(\mathrm{W} / \mathrm{m}^{2}\right) \times 0.0092 \text { (All Parts) }
\end{aligned}
$$$$
\text { ここで, } H_{\text {Arm }}, H_{\text {Trunk }}, H_{\text {Hip }}, H_{\text {Thigh }}, H_{\text {Calf }}, H_{\text {All }} \text { ，はそれぞ }
$$
れ腕部，体幹部，㾓部，下腿部，下肢部，全表面の熱流 束 $\left[\mathrm{W} / \mathrm{m}^{2}\right]$ である.

図7の各ブロックの回帰直線の切片は, ほぼ $34.0^{\circ} \mathrm{C}$ である.これは, 熱流束が $0 \mathrm{~W} / \mathrm{m}^{2}$ で熱の移動がない時 は, 埋め込み温度センサーの位置で設定した表面温度 $\left(=34.0^{\circ} \mathrm{C}\right)$ と濡れたスウェットスーツ上の表面温度が

\begin{tabular}{|c|c|c|c|c|}
\hline & $\begin{array}{l}\text { 夏ビジネス } \\
\text { スーツ(SB) }\end{array}$ & $\begin{array}{l}\text { 作業服 } \\
\text { (WC) }\end{array}$ & $\begin{array}{l}\text { ニッカポッカ } \\
(\mathrm{Ni})\end{array}$ & $\begin{array}{l}\text { Tyvek Model III } \\
\text { (Dupont)(Ty) }\end{array}$ \\
\hline $\begin{array}{l}\text { 着 } \\
\text { 衣 }\end{array}$ & $\begin{array}{l}\text { 1. ジャケット } \\
\text { 2. 長ズボン } \\
\text { 3. シャツ } \\
\text { 4. ネクタイ }\end{array}$ & 1. 作業服上下 & $\begin{array}{l}\text { 1. ジャケット } \\
\text { 2. ニッカポッカ }\end{array}$ & $\begin{array}{l}\text { 1. Tyvek Softwear } \\
\text { Model III }\end{array}$ \\
\hline $\begin{array}{l}\text { 共 } \\
\text { 通 } \\
\text { 部 } \\
\text { 分 }\end{array}$ & $\begin{array}{l}\text { 1. 下着(半袖シャ } \\
\text { ツ、パンツ) } \\
\text { 2. 手袋 } \\
\text { 3. 安全靴 } \\
\text { 4. 靴下 }\end{array}$ & $\begin{array}{ll}\text { 1. 下着(半袖シャ } & \text { ツ、パンツ) } \\
& \text { 、手袋 } \\
\text { 2. } & \text { 安全靴 } \\
\text { 3. } & \text { 靴下 }\end{array}$ & $\begin{array}{ll}\text { 1. 下着(半袖シャ } & \text { ツ、パンツ) } \\
& \text { 、手袋 } \\
\text { 2. } & \text { 安全靴 } \\
\text { 3. } & \text { 靴下 }\end{array}$ & $\begin{array}{l}\text { 1. 下着 (半袖シャ } \\
\text { ツ、パンツ) } \\
\text { 2. 手袋 } \\
\text { 3. 安全靴 } \\
\text { 4. 靴下 }\end{array}$ \\
\hline
\end{tabular}
等しいことを示し（2）の理論式に合致している．すな わち，表面温度の実測值が正確だったことを示してい る. 4 種類の表面温度 $\left(T_{\text {shell }}, T_{\mathrm{ws}}\right.$, 各ブロックの予測式 （6１0）で計算した温度，全ゾーンの予測式（11）で計 算した温度）を用いて計算した衣服の全潜熱抵抗を左か ら図 8 に示す. $T_{\text {shell }}$ で計算した全潜熱抵抗と $T_{\mathrm{ws}}$ で計算 した全潜熱抵抗の相対比の差は立位，歩行（0.96, 1.92,

表3 潜熱抵抗の測定に用いた衣服の組み合わせ 


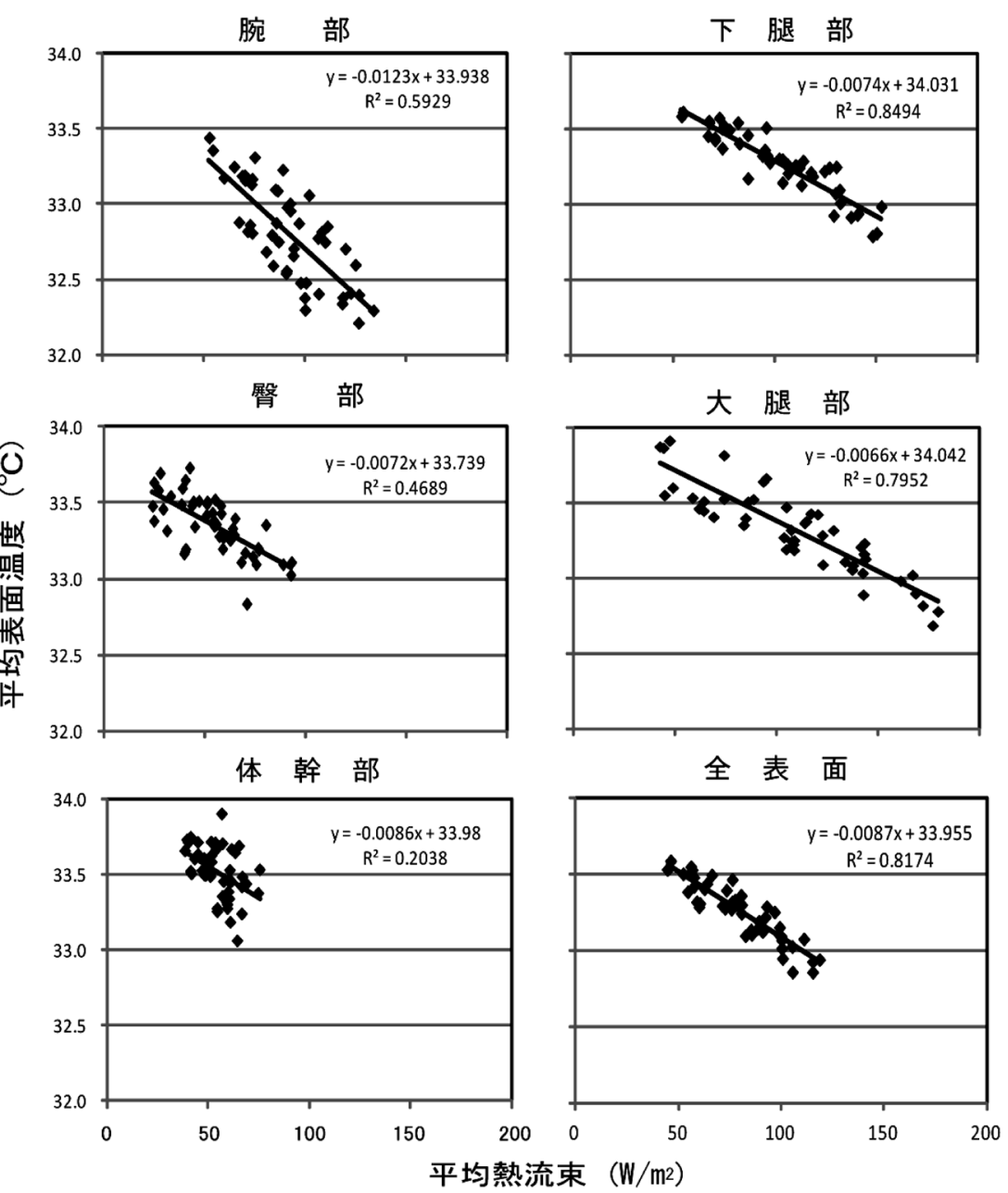

図7 各部位ごとの平均熱流束と平均皮膚温度との関連 4 種類の服, 4 種類の条件で測定した場合のデータをすべてプロットした.

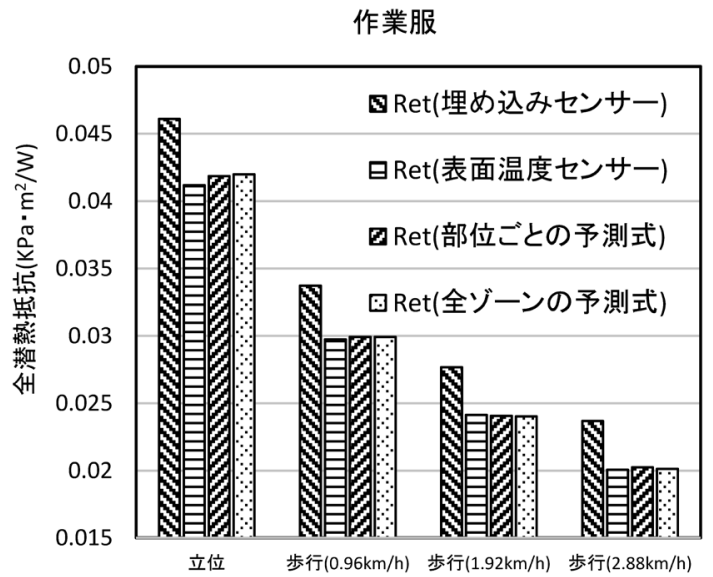

図8 作業服（表3）の立位, 歩行状態での全潜熱抵抗

$2.88 \mathrm{~km} / \mathrm{h}$ ）でそれぞれ $8.4,10.4,12.3,14.5 \%$ でありマネ キンからの放熱量が多いほど表面温度補正が重要である ことがわかった。

一度理論式を求めれば, 発熱量からスウェットスーツ 上の表面温度を求めることができる．表面温度を直接測 定することなく，潜熱抵抗を求めることが可能となっ た。

\section{5 まとめ}

ここではサーマルマネキンを使って我々が行った消防 服の顕熱抵抗測定と着衣潜熱抵抗測定の高精度化による 測定技術向上についての 2 件の研究紹介を行った. 夏季 の熱中症による業務上の災害を防止するには，作業服が もたらす暑熱負担 ${ }^{9)}$ を軽減することは重要な対策の一つ である．今後サーマルマネキンを使った作業服や防護服 の温熱特性の測定がますます重要となってくると思われ る.

ここで紹介した二つの研究以外にも, 我々はフットマ ネキンを使った靴の保温性の測定 ${ }^{11,12)}$ ，ヘッドマネキン を使った安全ヘルメットの通気性に関する研究 ${ }^{13)}$, 全身 マネキンを使った身体冷却用クールベストの冷却能力に 関する研究 ${ }^{14)}$ を行い, 業務上の温熱に関するストレスを やわらげるための研究を行っている.

\section{文献}

1）田村照子. 衣服と気候. 成山堂. 2013.

2) Tanabe S, Kobayashi K, Nakano J, Ozeki Y, Konishi M. Evaluation of thermal comfort using combined multimode thermoregulation $(65 \mathrm{MN})$ and radiation models and computational fluid dynamics (CFD). Energy Build. 2002; 34: 637-646. 
3）田辺新一. 居住環境の快適性研究動向一サーマルマネキン と人体モデル一. 特集サーマルマネキン最前線, 空気調和 衛生工学. 2010; 84: 3-9.

4) 郡逸平. 自動車室内の温熱環境評価法の標準化. 特集サー マルマネキン最前線，空気調和衛生工学. 2010; 84: 31-41.

5）上野哲, 澤田晋一. サーマルマネキンを使った防火服の顕 熱抵抗測定. 労働安全衛生研究. 2008; 1: 189-196.

6) ENV342. European Prestandard product specification (protection against cold)

7) ASTM. ASTM F1291 standard method for measuring the thermal insulation of clothing using a heated manikin. Annual Book of ASTM standards. Vol. 11.03, Conshohocken, PA: American Society for Testing and Materials. 2005.

8) ASTM. ASTM F2370 standard method for measuring the evaporative resistance of clothing using a sweating manikin. Vol. 11.03, Conshohocken, PA: American Society for Testing and Materials. 2005.

9) Taylor NA. Challenges to temperature regulation when working in hot environments. Ind. Health 2006; 331-344.
10) Ueno S, Sawada S. Correction of the evaporative resistance of clothing by the temperature of skin fabric on a sweating and walking thermal manikin. Text. Res. J. 2012; 82: 11431156.

11) Ueno S, Kuklane K, Holmer I, Sawada S. Thermal resistance of occupational footwear used in Japan. ICB2008. Proceedings CD-ROM Cloth-P07 12th. 2008.

12) Kuklane K, Ueno S, Sawada S, Holmer I. Testing cold protection according to EN ISO 20344: Is there any professional footwear that does not pass? Ann. Occup. Hyg. 2009; 53: 63-68.

13）上野哲, 澤田晋一. 発汗型ヘッドマネキンを用いた作業用 安全ヘルメットの通気性に関する研究. 第50回日本労衝衛 生工学会, 第31 回作業環境測定研究発表会抄録集. 2010; 194-195.

14) Ueno S, Sawada S. Estimation of cooling effect of ice packs by thermal manikin. Proceedings of 12th International Conference on Environmental Ergonomics, Slovenia. 2007; pp. 447-450. 